\title{
PENGARUH PENYANGRAIAN DENGAN TEKNOLOGI VIBRO-FLUIDIZED TERHADAP AKTIVITAS ANTIOKSIDAN BIJI KAKAO
}

\section{The Effect of Roasting Using Vibro-Fluidized Technology Towards The Level of Antioxidant Activity on Cocoa Beans}

\author{
Tri Yogo Wibowo*, Lamhot P. Manalu, Astuti, Jusuf Jakfar \\ Pusat Teknologi Agroindustri - Deputi TAB - Badan Pengkajian dan Penerapan Teknologi \\ Gedung 612 LAPTIAB, Kawasan Puspiptek, Setu - Tangerang Selatan 15314 \\ *Penulis Korespondensi: email: triyogaw@yahoo.com
}

\begin{abstract}
ABSTRAK
Proses penyangraian biji kakao dapat mempengaruhi mutu kakao. Akibat suhu yang tinggi pada proses penyangraian, aktivitas antioksidan biji kakao dapat menurun. Oleh karena itu, untuk mengurangi tingkat penurunan aktivitas antioksidan biji kakao maka perlu dilakukan proses penyangraian yang lebih efektif (waktu penyangraian yang lebih cepat dan pemanasan yang lebih merata). Penelitian ini bertujuan untuk mengetahui pengaruh penyangraian biji kakao secara cepat dan efektif dengan menggunakan alat vibro-fluidized roaster, sehingga penurunan aktivitas antioksidan biji kakao dapat dikurangi. Biji kakao yang tidak di fermentasi dipilih untuk disangrai menggunakan alat vibro-fluidized roaster atau disangrai menggunakan penyangrai konvensional. Proses penyangraian dilakukan pada suhu $140^{\circ} \mathrm{C}$ selama waktu tertentu sehingga kadar airnya mencapai 2-2.5\%. Selanjutnya, biji hasil sangrai dipecah dan dipisah antara nib kakao dengan kulit kakao. Nib kakao dianalisa antioksidannya dan laju penurunan kadar airnya. Hasil penelitian menunjukkan bahwa produk biji kakao yang dihasilkan dari proses penyangraian menggunakan vibro-fluidized roaster memiliki kandungan anti oksidan sebesar $46.86 \%$, sedangkan produk yang dihasilkan menggunakan penyangrai konvensional sebesar $38.16 \%$. Laju penurunan kadar air dari hasil penyangraian menggunakan alat vibro-fluidized roaster lebih cepat dari pada menggunakan penyangrai konvensional
\end{abstract}

Kata kunci : Biji Kakao, Roaster, Sangrai, Vibro-Fluidized

\begin{abstract}
A roasting process of cocoa beans can influence to the quality of cocoa beans product, specifically the use of high temperature on roasting process could reduce the activity of antioxidant. Therefore, in order to diminish levels of reducing activity of antioxidant on cocoa beans, it needs to manage the effectivity of a roasting process such as time and temperature. This research aims to determine the effect of length of roasting time using vibro-fluidized roaster which could reduce the decreasing of level the antioxidant activity of cocoa bean. In this experiment, the unfermented cocoa beans were selected for a roasting process using a vibro-fluidized roaster or roasted apparatus using conventional roasters. The roasting process was carried out at $140^{\circ} \mathrm{C}$ for a certain time resulted the water content reached $2-2.5 \%$. Furthermore, roasted beans were broken down and separated between cocoa nib with cocoa shell. The antioxiant activity of cocoa nib and the decreasing of water content were analyzed and the results showed that cocoa beans produced contains antioxidant $46.86 \%$ while the conventional products $38.16 \%$. It can be conclude that the rate of decreasing moisture content from roasting process using a vibro-fluidized roaster is faster than a conventional roaster
\end{abstract}

Keywords: Cocoa Beans, Roaster, Roasting, Vibro-Fluidized 
Jurnal Teknologi Pertanian Vol. 18 No. 1 [April 2017] 53-60

Pengaruh Penyangraian dengan Teknologi Vibro--Fluidized [Wibowo dkk.]

\section{PENDAHULUAN}

Senyawa flavonol diidentifikasi terkandung dalam buah, sayur, dan tumbuhan lainnya, misalnya apel, anggur ungu, anggur merah, cranberries, teh (Volikakis dan Efstathiou, 2005; Sukadana, 2009; Singh et al., 2011). Selain itu, salah satu produk pangan yang kaya akan senyawa flavanol adalah produk olahan kakao dan cokelat. Beberapa penelitian menunjukkan bahwa kakao mempunyai aktivitas antioksidan lebih tinggi dibandingkan teh dan anggur merah (Ruxton, 2009; Hodgson dan Croft, 2010; Martin et al., 2010; Patras et al., 2014; Corona et al., 2015; McKay et al., 2015). Besarnya jumlah flavanol yang identik dengan besarnya aktivitas antioksidan telah menyebabkan produk kakao menarik perhatian para peneliti maupun konsumen (Dasgupta dan Klein, 2014; Li et al., 2017). Aktivitas antioksidan kakao selain dipengaruhi oleh faktor genetik dan faktor lingkungan biofisik dan agronomis (Diantika et al., 2014), juga dipengaruhi oleh faktor pasca panen dan pengolahan yang meliputi proses penyimpanan, fermentasi, pengeringan dan proses penyangraian, serta prosesproses industrialisasi lainnya (Aroyeun et al., 2006; Bernaert et al., 2012; Ricketts et al., 2014; Abbey et al., 2016).

Proses pengeringan dan penyangraian biji kakao merupakan langkah-langkah penting pada proses pengolahan biji kakao (Daud et al., 2007; Hurst et al., 2011; Kumari et al., 2016). Pengeringan biji kakao bertujuan untuk menurunkan kadar air hingga sekitar 6-7\%. Penelitian yang dilakukan oleh Di Mattia et al. (2013) menunjukkan bahwa lamanya proses pengeringan biji kakao berpengaruh nyata terhadap kandungan procyanidin dan aktivitas antioksidan. Semakin lama proses pengeringan, maka proses perombakan senyawa-senyawa kimia atau penguraian senyawa polifenol yang terkandung dalam biji akan semakin tinggi. Penyangraian biji kakao dimaksudkan untuk mempermudah pelepasan kulit biji, pembentukan komponen flavor, pengurangan kadar air, dan perubahan warna dan senyawa kimia dalam biji kakao. Penyangraian biji kakao cara konvensional masih dilakukan dengan pemanasan pada tiga cara standar yaitu konduksi, konveksi, dan radiasi, menyebabkan pemanasan berlangsung lambat. Pada keadaan demikian senyawa flavanol akan banyak berubah karena lama terpapar oleh oksigen udara pada suhu relatif tinggi, sehingga berpengaruh terhadap aktivitas antioksidannya. Selama proses penyangraian, kandungan procyanidin dan kapasitas antioksidan biji kakao berkurang secara tajam sejalan dengan semakin tingginya suhu penyangraian (Arlorio et al., 2008).

Produk kakao yang ditujukan untuk produk pangan dan sekaligus produk kesehatan sangat membutuhkan proses pengolahan yang spesifik agar aktivitas antioksidan tetap dipertahankan dengan baik. Salah satu caranya adalah melakukan penyangraian pada suhu rendah dan waktu penyangraian yang lebih cepat. Peningkatan pengolahan dilakukan melalui proses penyangraian biji kakao yang cepat, sehingga diharapkan dapat dihasilkan produk kakao yang memenuhi kebutuhan kesehatan dan citarasa. Cara penyangraian alternatif nonkonvensional telah banyak dikembangkan antara lain penyangraian menggunakan inframerah, dan penyangraian berbasis dielectric heating oleh medan listrik frekuensi tinggi seperti frekuensi radio, ohmic heating, dan energi gelombang mikro (Richardson, 2001; Kyysiak, 2006; Widyotomo et al., 2006;). Penyangraian menggunakan metode vibro-fluidized yang dilakukan pada percobaan ini dimaksudkan untuk mengurangi penurunan kapasitas antioksidan kakao tanpa mengurangi citarasa kakao. Penyangraian metode vibro-fluidized ini menggabungkan panas inframerah dan sistem getaran yang akan membantu proses pemecahan biji, sehingga panas akan mudah ditransfer ke dalam biji. Proses penyangraian dengan cara vibro-fluidized diharapkan dapat lebih cepat dan berlangsung pada suhu yang relatif lebih rendah dibandingkan cara konvensional, sehingga akan diperoleh produk biji kakao yang memiliki fungsi untuk kesehatan yang baik dan citarasa kakao yang tinggi.

\section{BAHAN DAN METODE}

\section{Bahan}

Bahan baku untuk penelitian ini adalah biji kakao kering hasil fermentasi dan non fermentasi yang diperoleh dari Gapoktan Reso Pammase, desa Komba, kecamatan Larompong, kabupaten Luwu, Sulawesi Selatan. Bahan kimia yang dipakai butylated 
hydroxyanisole (BHA), 1,1-Diphenyl-2-picryl-hydrazyl (DPPH), etanol, dan semua bahan kimia yang dipakai sebagian besar adalah analytical grade dari Sigma Chemical Company.

Alat

Peralatan utama yang digunakan meliputi alat penyangrai vibro-fluidized roaster (VFR) berkapasitas 30-50 kg/jam yang memiliki bagian-bagian yang terdiri dari vibrating unit, chamber mild steel, platform mild steel, rotary feeder mild steel, dan hopper mild steel. Alat VFR ini juga dilengkapi dengan motor penggerak, pemanas infrared, sensor suhu, temperatur kontrol digital, dan control panel. Sementara alat penyangrai konvensional berupa drum yang berputar yang dipanaskan menggunakan pemanas elpiji, dilengkapi dengan indikator suhu, dan motor penggerak. Alat ekstraksi polifenol, rotavapor vakum, spektrofotometer, Adam moisture analysis model AMB 50.

\section{Metode}

Penelitian ini dilakukan di Laboratorium Teknologi Agroindustri, Laboratoria Pengembangan Teknologi Industri Agro dan Bioteknologi (LAPTIAB), Badan Pengkajian dan Penerapan Teknologi, dan di PT Kerta Leksana, Cimahi Bandung. Uji analisa aktivitas antioksidan dilakukan di Laboratorium Teknologi Bioindustri LAPTIAB.

Analisa yang dilakukan terhadap bahan baku dan produk meliputi pengukuran kadar air dan aktivitas anti oksidan. Pengukuran kadar air dilakukan dengan menggunakan alat moisture analyzer. Kadar air dihitung berdasarkan berat awal sampel dan berat akhir sampel setelah tidak terdapat perubahan berat saat pemanasan sampel pada suhu $125-126^{\circ} \mathrm{C}$. Pengukuran anti oksidan dilakukan dengan menggunakan analisis DPPH (1,1-diphenyl2-picrylhydrazyl). Aktivitas antioksidan diuji dengan mengukur penurunan DPPH memakai alat spektrofotometer pada panjang gelombang $517 \mathrm{~nm}$. Penurunan DPPH disebabkan oleh adanya donor $\mathrm{H}$ dari antioksidan pada DPPH menjadi DPPH-H, sehingga molar penyerapan pada panjang gelombang $517 \mathrm{~nm}$ berubah dari 9660 menjadi 1640, dan warna berubah dari ungu menjadi kekuningan.

\section{Pelaksanaan Penelitian}

Biji kakao baik yang difermentasi maupunyang tidak difermentasi, dikeringkan dibawah sinar matahari sampai kadar airnya turun menjadi lebih kurang 7\%. Biji kakao kering tersebut selanjutnya diukur kadar air dan aktivitas anti oksidannya. Berdasarkan nilai aktivitas antioksidannya, biji kakao nonfermented dipilih untuk dilakukan proses penyangraian menggunakan alat VFR dan penyangrai konvensional.

Proses penyangraian dilakukan dengan menggunakan alat VFR dan penyangrai konvensional seperti yang terlihat pada Gambar 1. Pada proses penyangraian menggunakan alat VFR seperti pada Gambar 1a. Sejumlah biji kakao kering diumpankan melalui sebuah hopper dan dibantu dengan rotary feeder masuk ke ruang pemanas yang diatur pada suhu 140 ${ }^{\circ} \mathrm{C}$. Pada ruang pemanas, biji kakao bergerak ke bawah dengan laju yang bisa diatur mengikuti kecepatan getaran dan tingkat kemiringan ruangan pemanas. Biji kakao yang keluar dari alat penyangrai ditampung dan dibiarkan dingin. Selanjutnya dipisahkan antara kulit biji dan nib kakao. Nib kakao yang dihasilkan, dianalisa kadar air dan aktivitas anti oksidannya. Pada proses penyangraian secara konvensional seperti pada Gambar 1b. Sejumlah biji kakao kering dimasukkan ke dalam tabung pemanas yang dilengkapi dengan pengaduk, sensor suhu, dan sumber pemanas gas LPG. Pemanasan dilakukan pada suhu $140^{\circ} \mathrm{C}$ selama 40 menit, dilanjutkan pemisahan kulit biji dan nib kakao. Nib kakao yang dihasilkan dianalisa kadar air dan aktivitas antioksidannya.

\section{HASIL DAN PEMBAHASAN}

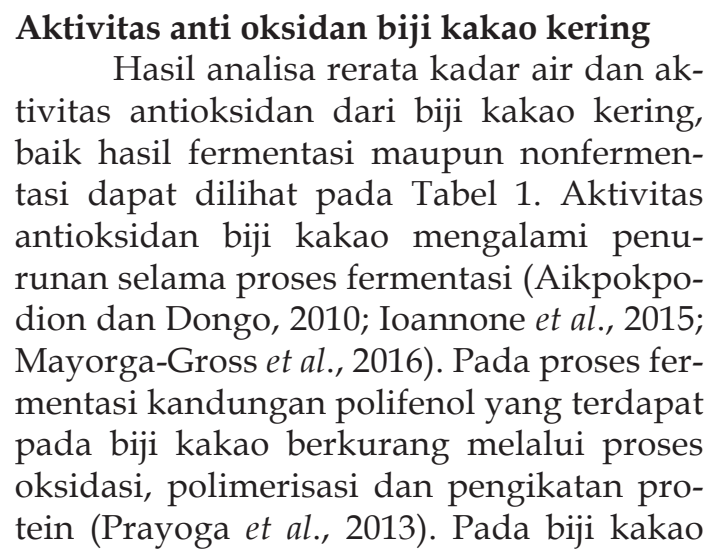


Jurnal Teknologi Pertanian Vol. 18 No. 1 [April 2017] 53-60

Pengaruh Penyangraian dengan Teknologi Vibro--Fluidized [Wibowo dkk.]

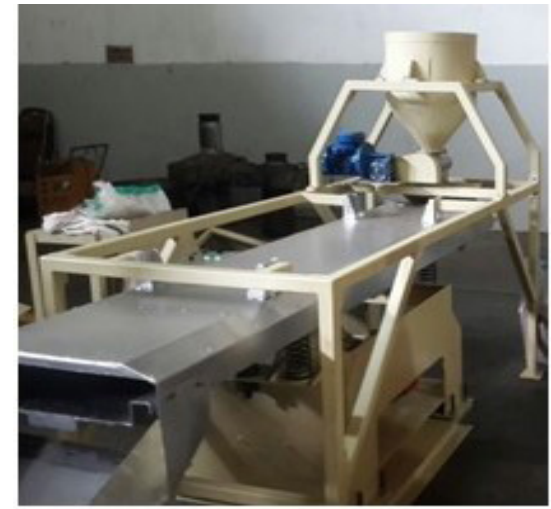

(a)

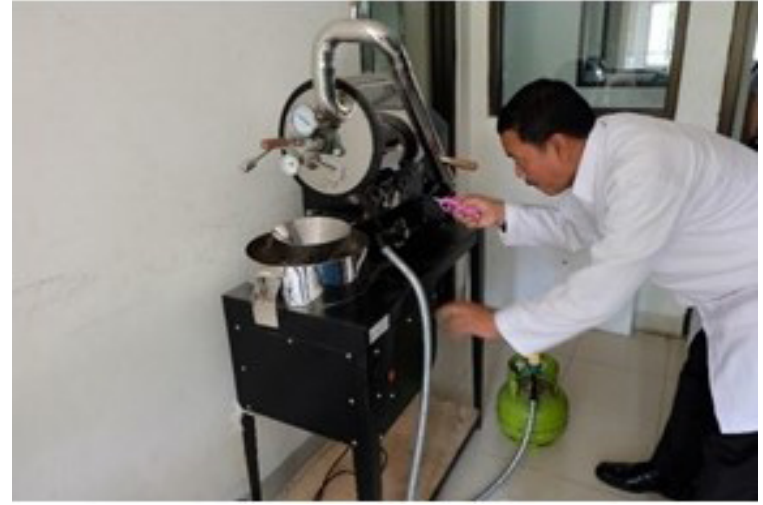

(b)

Gambar 1. Alat penyangrai biji kakao. Vibro-fluidized roaster (a); penyangrai konvensional (b)

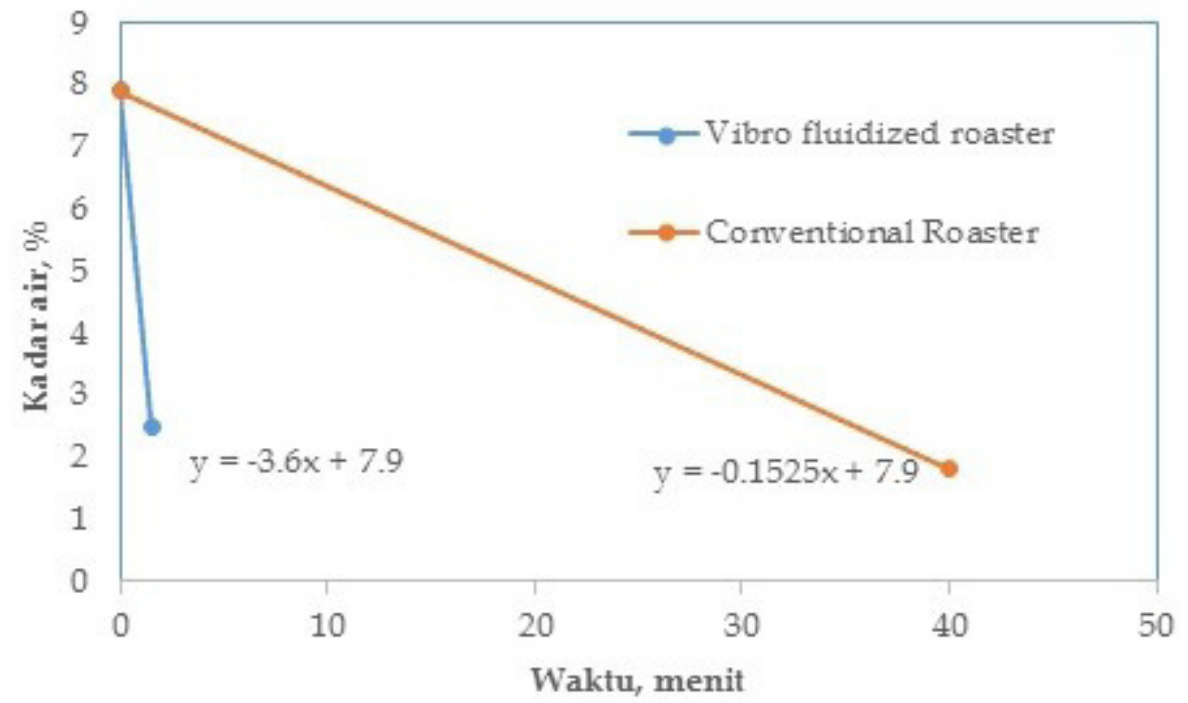

Gambar 2. Pengaruh waktu penyangraian terhadap perubahan kadar air biji kakao

Tabel 1. Pengaruh fermentasi terhadap kualitas biji kakao setelah pengeringan

\begin{tabular}{lcc}
\hline Biji kakao & Kadar air (\%) & Aktivitas antioksidan (\%) \\
\hline Fermented & 7.5 & 30.338 \\
Nonfermented & 7.9 & 40.576 \\
\hline
\end{tabular}

Tabel 2. Pengaruh metode penyangraian terhadap aktivitas antioksidan biji kakao

\begin{tabular}{lccc}
\hline Metode roasting & $\begin{array}{c}\text { Kadar air } \\
\mathbf{( \% )}\end{array}$ & $\begin{array}{c}\text { Aktivitas antioksidan } \\
(\mathbf{\%})\end{array}$ & Setara $\boldsymbol{\mu g}$ BHA/g sampel \\
\hline Vibro-fluidized roasting & $2.5 \%$ & 46.860 & 100775.877 \\
Konvensional roasting & $1.8 \%$ & 38.162 & 33349.484 \\
\hline
\end{tabular}


terfermentasi, senyawa polifenol juga menyebar keluar dari sel penyimpanannya dan kemudian mengalami oksidasi membentuk senyawa bermolekul tinggi (Bernaert et al., 2012; Martin dan Ramos, 2016). Pada proses fermentasi biji kakao, senyawa polifenol mengalami penguraian oleh mikroorganisma sehingga aktivitas antioksidannya lebih rendah. Hasil pengukuran kadar air terlihat bahwa biji kakao kering terfermentasi dan nonfermentasi memiliki kadar air yang relatif sama. Kadar air biji kakao lebih kurang $7 \%$ mencukupi syarat untuk proses penyangraian. Berdasarkan data pada Tabel 1 , maka proses penyangraian menggunakan biji kakao nonfermentasi kering.

\section{Pengaruh Penyangraian Terhadap Kadar} Air dan Aktivitas Antioksidan Biji Kakao

Perubahan kadar air biji kakao selama penyangraian dapat dilihat pada Gambar 2. Biji kakao yang disangrai dengan VFR dianggap mengikuti aliran horizontal dengan waktu tinggal tertentu. Selama penyangraian, $1 \mathrm{~kg}$ biji kakao menggunakan VFR pada waktu tinggal 1.5 menit, kadar air biji kakao turun dengan cepat, yang hasilnya ditunjukkan pada Gambar 2. Apabila laju penurunan kadar air mengikuti garis lurus (Supriyanto et al., 2007), penyangraian VFR mengikuti persamaan $\mathrm{KA}=-3.6 \mathrm{t}+7.9$, sedangkan penyangraian konvensional mengikuti persamaan $\mathrm{KA}=-0.1525 \mathrm{t}+7.9$, dengan KA adalah nilai kadar air, $\mathrm{t}$ adalah lama penyangraian. Kecepatan penurunan kadar air selama penyangraian VFR (laju tetap) sekitar 3.6\% per menit. Sementara itu, penurunan kadar air selama penyangraian konvensional sampai dengan 40 menit ditunjukkan pada Gambar 2, dengan laju tetap sebesar $0.1525 \%$ per menit, dibandingkan dengan penyangraian konvensional, laju penurunan kadar air VFR 24 kali lebih cepat (Zzaman dan Yang, 2013).

Penurunan kadar air yang lebih cepat selama penyangraian VFR mungkin disebabkan oleh panas yang terdistribusi pada biji kakao lebih merata dan adanya getaran menyebabkan tumbukan antar biji semakin kuat. Biji kakao yang saling bertumbukan selama proses penyangraian, mengakibatkan kulit biji kakao retak sehingga panas lebih mudah masuk ke dalam biji kakao. Panas yang masuk ke dalam biji mengakibatkan timbulnya tekanan uap yang kemudian secara aktif mendorong air dan uap air dari bagian dalam biji menuju ke permukaan biji. Adanya gerakan bahan yang turun menyebabkan uap air yang ada di permukaan biji mudah menguap. Dengan demikian, tekanan yang terbentuk dan aliran bahan yang turun berperan sebagai pressure-driven flow dan menjadi daya dorong tambahan terhadap perpindahan molekul air selain diffusi yang disebabkan oleh perbedaan konsentrasi. Makin tinggi suhu bahan makin besar tekanan uap air yang terbentuk sehingga perpindahan molekul air dan uap air menjadi semakin cepat. Perpindahan molekul air tersebut dipercepat oleh pumping effect dimana air meninggalkan lapisan permukaan bahan tanpa melalui penguapan (Datta dan Anantheswaran, 2001; Murthy et al., 2008; Nagaraju dan Bhattacharya, 2010; Hii et al., 2013).

Aktivitas antioksidan hasil penyangraian cara konvensional lebih kecil dibandingkan aktivitas antioksidan hasil penyangraian cara VFR. Hal ini sangat dipengaruhi oleh lamanya waktu penyangraian. Semakin lama proses penyangraian, maka proses perombakan senyawa-senyawa kimia atau penguraian senyawa polifenol yang terkandung dalam biji akan semakin tinggi (Arlorio et al., 2008).

Selama penyangraian biji kakao menggunakan VFR dan konvensional, aktivitas antioksidan menjadi lebih kecil. Penurunan aktivitas antioksidan ini disebabkan oleh penurunan kadar polifenol dalam biji kakao (Ribereau-Gayon, 1972; Żyżelewicz et al., 2016; Kwak et al., 2017). Penyangraian biji kakao dimaksudkan untuk mempermudah pelepasan kulit biji, pembentukan komponen flavor, pengurangan kadar air, memudahkan pengeluaran lemak dari dalam biji dan perubahan warna serta perubahan senyawa kimia dalam biji kakao. Pada proses penyangraian senyawa polifenol mengalami oksidasi yang dipercepat oleh pengaruh suhu dan lama penyangraian. Pada oksidasi polifenol, atom $\mathrm{H}$ pada gugus $\mathrm{OH}$ diambil oleh senyawa oksidator menjadi senyawa lain. Makin banyak atom $\mathrm{H}$ yang diambil, makin kecil kadar polifenol dalam bahan (Riberea-Gayon, 1972), dengan demikian aktivitas antioksidannya akan semakin menurun.

\section{SIMPULAN}

Penyangraian menggunakan VFR berlangsung lebih cepat dibandingkan dengan 
Jurnal Teknologi Pertanian Vol. 18 No. 1 [April 2017] 53-60

Pengaruh Penyangraian dengan Teknologi Vibro--Fluidized [Wibowo dkk.]

cara konvensional ditunjukkan oleh laju penurunan kadar yang 24 kali lebih cepat pada rate constant $3.6 \%$ per menit. Penyangraian menggunakan VFR juga menghasilkan nib kakao yang memiliki aktivitas antioksidannya lebih tinggi dibandingkan dengan cara konvensional. Aktivitas antioksidan selama penyangraian menggunakan VFR dan konvensional nilainya berkisar setara 100775.88 $\mu \mathrm{g}$ BHA/g sampel dan $33349.48 \mu \mathrm{g}$ BHA/g sampel.

\section{UCAPAN TERIMA KASIH}

Terima kasih kepada Kementerian Riset dan Pendidikan Tinggi Republik Indonesia atas bantuan dana penelitian melalui program Insinas 2016, serta kepada PT Kerta Leksana Cimahi, Bandung atas peminjaman alat vibrofluidized roaster untuk pelaksanaan penelitian ini.

\section{DAFTAR PUSTAKA}

Abbey, P, Tomlinson, P, R, Branston, J, R. 2016. Perceptions of governance and social capital in ghana's cocoa industry. Journal of Rural Studies. 44:153-163

Aikpokpodion, P, E, Dongo, L, N. 2010. Effects of fermentation intensity on polyphenols and antioxidant capacity of cocoa beans. Int. J. Sustain. Crop Prod. 5(4):66-70

Arlorio, M, Locatelli, M, Travaglia, F, Coïsson, J, D, Del Grosso, E, Minassi, A, Appendino, G, Martelli, A. 2008. Roasting impact on the contents of clovamide ( $N$-caffeoyl-L- DOPA) and antioxidant activity of cocoa beans (Theobroma cacao L.). Food Chemistry. 106(3):967-975

Aroyeun, S, O, Ogunbayo, J, O, Olaiya, A, O. 2006. Effect of modified packaging and storage time of cocoa pods on the commercial quality of cocoa beans. British Food Journal. 108(2):141-151

Bernaert, H, Blondeel, L, Allegaert, L, Lohmueller, T. 2012. 'Industrial treatment of cocoa in chocolate production: health implication'. Dalam Conti A, Paoletti,
R, Poli A, Visiolo, F (ed.). Chocolate and Health. Springer-Verlag, Italia

Bouyed, J, Hoffmann, L, Bohn, T. 2011. Total phenolics, flavonoids, anthocyanins and antioxidant activity following simulated gastro-intestinal digestion and dialysis of apple varieties: Bioaccessibility and potential uptake. Food Chemistry. 128(1):14-21

Corona, O, Squadrito, M, Vento, G, Tirelli, A, Di Stefano, R. 2015. Over-evaluation of total flavonoids in grape skin extracts containing sulphur dioxide. Food Chemistry. 172:537-542

Dasgupta, A, Klein, K. 2014. 'Tea, Coffee, and Chocolate: Rich Sources of Antioxidants'. Dalam Dasgupta, A, Klein, K. Antioxidants in Food, Vitamins and Supplements. Elsevier, USA

Datta, AK, Anantheswaran, RC. 2001. Handbook of Microwave Technology for Food Application. Marcel Dekker, USA

Daud, W, R, W, Talib, M, Z, M, Kyi, T, M. 2007. Drying with Chemical Reaction in Cocoa Beans. Drying Technology. 25(5):867-875

Diantika, F, Sutan, S, M, Yulianingsih, R. 2014. Pengaruh lama ekstraksi dan konsentrasi pelarut etanol terhadap ekstraksi antioksidan biji kakao (Theobroma cacao L.). Jurnal Teknologi Pertanian. 15(3):159-164

Di Mattia, C, Martuscelli, M, Sacchetti, G, Scheirlinck, I, Beheydt, B, Mastrocola, D, Pittia, P. 2013. Effect of fermentation and drying on procyanidins, antiradical activity and reducing properties of cocoa beans. Food and Bioprocess Technology. 6(12):3420-3432

Hii, CL, Jangam, SV, Chiang CL, Mujumdar, AS. 2013. Processing and drying of foods, vegetables and fruits. Dilihat 20 November 2016. <http://www.arunmujumdar.com/file/Publications/ books / Processing \% 20and \% 20Drying $\% 20$ of $\% 20 \mathrm{FVF}$.pdf $>$

Hodgson, J, M, Croft, K, D. 2010. Tea flavonoids and cardiovascular health. Molecular Aspects of Medicine. 31(6):495-502

Hurst, W, J, Krake, S, H, Bergmeier, S, C, Payne, M, J, Miller, K, B, Stuart, D, A. 2011. Impact of fermentation, drying, roasting and Dutch processing on flavan-3-ol stereochemistry in cacao beans and cocoa ingredients. Chem. Cent. J. 5:53 
Ioannone, F, Di Mattia, C, D, de Gregorio, M, Sergi, M, Serafini, M, Sacchetti, G. 2015. Flavanols, proanthocyanidins and antioxidant activity changes during cocoa (Theobroma cacao L.) roasting as affected by temperature and time of processing. Food Chemistry. 174:256-262

Kumari, N, Kofi, K, J, Grimbs, S, D'Souza, R, N, Kuhnert, N, Vrancken, G, Ullrich, M, S. 2016. Biochemical fate of vicilin storage protein during fermentation and drying of cocoa beans. Food Research International. 90:53-65

Kwak, H, S, Ji, S, Jeong, Y. 2017. The effect of air flow in coffee roasting for antioxidant activity and total polyphenol content. Food Control. 71:210-216

Kyysiak, W. 2006. Influence of roasting conditions on coloration of roasted cocoa beans. Journal of Food Engineering. 77(3):449-453

Li, D, Li, B, Ma, Y, Sun, X, Lin, Y, Meng, X. 2017. Polyphenols, anthocyanins, and flavonoids contents and the antioxidant capacity of various cultivars of highbush and half-high blueberries. Journal of Food Composition and Analysis. 62:84-93

Martin, M, A, Ramos, S. 2016. Cocoa polyphenols in oxidative stress: Potential health implications. Journal of Functional Foods. 27:570-588

Martin, M, A, Serrano, A, B, G, Ramos, S, Pulido, M, I, Bravo, L, Goya, L. 2010. Cocoa flavonoids up-regulate antioxidant enzyme activity via the ERK1/2 pathway to protect against oxidative stress-induced apoptosis in HepG2 cells. The Journal of Nutritional Biochemistry. 21(3):196-205

Mayorga-Gross, A, L, Quirós-Guerrero, L, M, Fourny, G, Vaillant, F. 2016. An untargeted metabolomic assessment of cocoa beans during fermentation. Food Research International. 89:901-909

McKay, D, L, Oliver Chen, C, Y, Zampariello, C, A, Blumberg, J, B. 2015. Flavonoids and phenolic acids from cranberry juice are bioavailable and bioactive in healthy older adults. Food Chemistry. 168:233-240

Murthy, K, V, Ravi, R, Bhat, K, K, Raghavarao, K, S, M, S. 2008. Studies on roasting of wheat using fluidized bed roaster. Journal of Food Engineering. 89(3):336-342
Nagaraju, V, D, Bhattacharya, S. 2010. Roasting green coffee beans using spouted bed roaster: changes in physical characteristics. J. Food Sci Technol. 47(6):674-677

Patras, M, A, Milev, B, P, Vrancken, G, Kuhnert, N. 2014. Identification of novel cocoa flavonoids from raw fermented cocoa beans by HPLC-MS. Food Research International. 63:353-359

Prayoga, R, D, Murwani, R, Anwar, S. 2013. Polyphenol extracts from low quality cocoa beans: antioxidant, antibacterial and food colouring properties. IFRJ. 20(6):3275-3281

Ribereau-Gayon, P. 1972. Plant Phenolic. Hafner Publishing Company, New York

Richardson, P. 2001. Thermal Technologies in Food Processing. CRC Press, UK

Ricketts, K, D, Turvey, C, G, Gomez, M, I. 2014. Value chain approaches to development: Smallholder farmer perceptions of risk and benefits across three cocoa chains in Ghana. Journal of Agribusiness in Developing and Emerging Economies. 4(1):2-22

Ruxton, C, H, S. 2009. The health effects of black tea and flavonoids. Nutrition $\mathcal{E}$ Food Science. 39(3):283-294

Singh, A, P, Wilson, T, Luthria, D, Freeman, M, R, Scott, R, M, Bilenker, D, Shah, S, Somasundaram, S, Vorsa, N. 2011. LC-MS-MS characterisation of curry leaf flavonols and antioxidant activity. Food Chemistry. 127(1):80-85

Sukadana, I, M. 2009. Senyawa antibakteri golongan flavonoid dari buah belimbing manis (averrhoa carambola Linn. L). Jurnal Kimia. 3(2):109-116

Supriyanto, Haryadi, Rahardjo, B, Marseno, D, W. 2007. Perubahan suhu, kadar air, warna, kadar polifenol dan aktivitas antioksidatif kakao selama penyangraian dengan enerji gelombang mikro. AGRITECH. 27(1):18-26

Volikakis, G, J, Efstathiou, C, E. 2005. Fast screening of total flavonols in wines, tea-infusions and tomato juice by flow injection/adsorptive stripping voltammetry. Analytica Chimica Acta. 551(1-2):124-131

Widyotomo, S, Mulato, S, Suharyanto, E. 2006. Optimasi mesin sangrai tipe silinder horizontal untuk penyangraian biji kakao. Pelita Perkebunan. 22(2):136-158 
Jurnal Teknologi Pertanian Vol. 18 No. 1 [April 2017] 53-60

Pengaruh Penyangraian dengan Teknologi Vibro--Fluidized [Wibowo dkk.]

Zzaman, W, Yang, T, A. 2013. Moisture, Color and Texture Changes in Cocoa beans during Superheated Steam Roasting. Journal of Food Processing and Preservation. 38(3):1364-1370
Żyżelewicz, D, Krysiak, W, Oracz, J, Sosnowska, D, Budryn, G, Nebesny, E. 2016. The influence of the roasting process conditions on the polyphenol content in cocoa beans, nibs and chocolates. Food Research International. 89:918-929 